Рахманов Віталій, доктор педагогічних наук, доцент Національний університет оборони України імені Івана Черняховського, м. Київ

ORCID ID 0000-0002-7180-4087

DOI: $10.33099 / 2617-1775 / 2021-01 / 279-288$

\title{
ОСНОВНІ ПІДХОДИ ДО СИСТЕМИ ПРОФЕСІЙНОЇ ВІЙСЬКОВОЇ ОСВІТИ В УКРАЇ̈I
}

У статті розглядаються зміни, щзо відбуваються останнім часом, у системі професійної військової освіти в Україні. Проаналізовано системний підхід до навчання, щуо забезпечує методологію для аналізу потреби у навчанні, визначення найбільи доречної навчальної стратегії, розробки та проведення навчальних та освітніх заходів, а також оцінки та підтвердження результатів, щзо забезпечують зворотний зв'язок для вдосконалення компетентностей військових фахівців, де поруч з освітою необхідно враховувати умови служби, стимули та мотивацію. Запропоновані принциипи професійної військової освіти, які забезпечуються на основі безперервного розвитку військових фахівців й залишаються невідємною складовою вищої освіти Украӥни. Для забезпечення якості професійної військової освіти визначена система навчання щуодо спільної підготовки офічерського складу тактичного,оперативного та стратегічного рівня Збройних Сил України та їхніх складових сил безпеки і оборони з метою набуття військовими фахівиями нових компетентностей, операційної сумісності на основі стандартів прийнятих у збройних силах держав-членів НАТО. .

Ключові слова: професійна військова освіта, набуття компетентностей, підготовка військових фахівиів, освітня діяльність.

Постановка проблеми. Зацікавленість національної безпеки і оборони пов'язано із запобіганням виникненню та розвитку збройних конфліктів на території держави, із забезпеченням ії здатності протистояти зовнішній агресії, вимагають від Збройних Сил України постійно підтримувати та розширювати свої можливості, протидіяти наявним і потенційним загрозам, ураховувати зміни, що відбуваються у збройних силах противника, завчасно й адекватно реагувати на зміни форм і способів ведення збройної боротьби, іiі характеру, основних принципів, ураховувати загальні зміни в безпековому, стратегічному й операційному середовищі.

Вирішення проблем, пов'язаних із забезпеченням інтересів національної безпеки і оборони, не обмежується виключно застосуванням Збройних Сил держави, які мають співпрацювати, проводити спільні операції та заходи 3 іншими складовими сил безпеки й оборони. Це потребує розширення можливостей сумісності не тільки на рівні видів та родів $3 \mathrm{C}$, але й на рівні міжвідомчої взаємодії та координації, а з урахуванням перспектив інтеграції до НАТО - забезпечення сумісності під час планування та проведення спільних операцій. Водночас мають бути створені умови для забезпечення сумісності видів та родів 3С з підрозділами інших складових сил безпеки і оборони на всіх рівнях, що має на меті отримання якісної переваги, як основи успішного 
застосування військової сили, на підгрунті професіоналізації військової освіти, сучасний стан якої характеризується інституційною розгалуженістю, традиційною орієнтацією на фундаментальну підготовку. Сучасна система військової освіти має орієнтуватись на конкретні потреби i завдання функціональної сфери, забезпечувати постійне підвищення рівня професійної підготовки та кваліфікації офіцерів і військових фахівців ЗС України, інших складових сил безпеки і оборони, що вимагає застосування нових підходів до формування змісту професійної військової освіти 3 метою забезпечення досягнення високого рівня операційної сумісності, міжвідомчої взаємодії та координації під час планування і проведення спільних операцій на рівні об'єднаних штабів тощо за стандартами та процедурами НАТО.

Аналіз останніх досліджень і публікацій. Результати аналізу наукових праць щодо системи професійної військової освіти в Україні вказують на те, що окремі аспекти розробки теорії та вдосконалення системи розглядалися з різних точок зору і були предметом уваги широкого кола науковців. Акцент робився у галузі військової освіти на формуванні та розвитку професійно важливих рис особистості (А. Галімов, О. Діденко, Д. Іщенко, В. Мірошніченко, Б. Олексієнко, О. Ставицький, В. Ягупов). В основу побудови методичної системи навчання покладені ідеї відомих вчених А. Автушенка, В. Баранівського, О. Бойка, Т. Мацевка, М. Руденка, В. Стасюка та ін. Широке коло підготовки військових фахівців висвітлено у працях В. Береки, Р. Гуревича, Й. Гушеля, О. Торичного та ін.

Метою статті є запровадження основних підходів до навчання військових фахівців для підвищення ефективності функціонування системи професійної військової освіти в Україні.

Виклад основного матеріалу. Професійна військова освіта спрямована на підготовку фахівця, який здатний ефективно виконувати службові обов'язки у мирний час та бойових умовах, особливо у всіх складових сектора безпеки та оборони країни. Тому професійна військова освіта має бути прогнозованою, систематизованою, спланованою, розробленою, здійсненою та керованою в усіх його проявах систематичним та оптимальним способом. Управління системою професійною військовою освітою дозволяє ефективніше використовувати ресурси, зменшити помилки, неправильні тлумачення та забезпечити оптимальність системи в цілому.

Професійна військова освіта застосовує принципи для надання сукупності знань та інтелектуальних навичок, на основі яких, судження серед сумнівних фактів, інформації та ідей можуть бути критично досліджені, оцінені та інтерпретовані. Професійна військова освіта базується на принципах: системності, інтегрованості, динамічності, інноваційності, інституційності, відповідальності, організаційності, індивідуальності, легітимності, гуманістичної спрямованості, зв'язку з життям, співпраці, послідовності, науковості, наочності, доступності, інтерактивності, самостійності тощо. Вхідні та вихідні дані системи професійної військової освіти змінюються залежно від типу навчання. Принципи навчальної системи професійної військової освіти 
однакові для створення інструкторських занять, навчань чи академічних програм, а також для проведення та управління навчальною діяльністю.

Професійна військова освіта грунтується на системному підході, яка враховує всі наслідки тієї чи іншої умови чи групи умов. Усі частини працюватиме разом, щоб забезпечити ефективність системи в цілому. Використання системного підходу враховує гнучкі умови впровадження результатів навчання, що впливають на процеси здобуття компетентностей військовими фахівцями (наприклад, зміни щодо набору та відбору, оперативних вимог, бюджетів чи закупівель обладнання можуть вплинути на систему підготовки військових фахівців). Для досягнення освітніх цілей слід керуватися механізмом зворотного зв'язку, що дозволяє ефективно реагувати та адаптуватись у сучасних умовах. Тому освітня система збирає відгуки 3 багатьох джерел інформації, перевіряє, оцінює та узагальнює результати діяльності. Крім того, система професійної військової освіти використовує систематичний підхід для розвитку освітньої діяльності. Застосування цих підходів дозволить вирішити проблемні питання та призвести до дій. Коли для усунення прогалин потрібні рішення для навчання, застосовують стратегію розробки програми та іï викладання. Для забезпечення освітньої діяльності необхідно враховувати ресурси, витрати та кількість необхідного особового складу.

Системний підхід, що використовується, забезпечує методологію для аналізу потреби у навчанні, визначення найбільш доречної навчальної стратегії, розробки та проведення навчальних та освітніх заходів, а також оцінки та підтвердження результатів, що забезпечують зворотний зв'язок для початку вдосконалення компетентностей. Цей цикл забезпечує постійний розвиток, який є фундаментальним для актуальності освітньої системи. У системному підході до навчання використовується індивідуальна та колективна підготовка.

В той час, коли індивідуальна підготовка призначена для задоволення потреб у кар'єрному розвитку особи, колективна підготовка фокусується на поєднаних навичках та знаннях, необхідних для підготовки військових формувань до бойового застосування. Колективна підготовка надає можливості підтримувати загальні знання, навички та можливості у військовій професії, набуті за допомогою індивідуальної підготовки та навчання (наприклад, щорічні індивідуальні стандарти бойових завдань), а також професійні знання, навички та можливості (наприклад, командно-штабні навчання), які дозволяють військовим фахівцям виконувати завдання. Колективна підготовка - це одночасне та послідовне виконання відповідних індивідуальних завдань у складі навчальних груп для отримання групових результатів. Колективна підготовка повторює або імітує оперативні умови, за яких передбачається виконання бойових завдань $[1,2]$.

У військовому підрозділі кожний командир відповідає за колективну підготовку та звітування свого підрозділу про стан і бойову готовність військ, що відображає стратегічні вказівки щодо колективної підготовки та забезпечує детальний розподіл ресурсів для підтримки проектування, планування та проведення спільних, інтегрованих та комбінованих тренувань та навчань. Це 
спрямовує командирів підрозділів до непередбачених ситуацій, підтримує поточні зобов'язання та застосовує ресурси для забезпечення ефективного використання військового потенціалу.

Після того, як військові фахівці отримають знання, навички та можливості шляхом індивідуальної підготовки та навчання, вони переходять до колективної підготовки, щоб навчитися застосовувати свої індивідуальні навички в загальних операційних умовах. Колективна підготовка - це механізм, за допомогою якого командир організовує навчання кваліфікованих військовослужбовців, за допомогою індивідуальної підготовки, для створення компетентних, згуртованих та дисциплінованих підрозділів, які можуть працювати в реалістичних термінах готовності. Структура колективної підготовки розподілена від стратегічного до тактичного рівня. Колективні навчальні заходи плануються, керуються та координуються для підтримки основного призначення Збройних Сил. Це навчання та підготовка $\epsilon$ фундаментальними для успішного проведення операцій. Колективна підготовка передбачає створення, тиражування або імітацію робочих умов, за яких будуть виконуватися завдання. Розробка колективної підготовки використовує ті самі принципи, що і індивідуальна підготовка, хоча в системному підході вимоги та результати різняться.

Таблиця 1

\begin{tabular}{|c|c|c|}
\hline Eтап & Індивідуальна підготовка & Колективна підготовка \\
\hline Аналіз & $\begin{array}{l}\text { Список навчальних завдань: } \\
\text { • Обгрунтування вибору / } \\
\text { відхилення. } \\
\text { • Пропоновані навчальні стратегії. } \\
\text { •Кваліфікаційний стандарт }\end{array}$ & $\begin{array}{l}\text { Стандарти виконання бойових } \\
\text { завдань: } \\
\text { • Визначення аудиторії початкової } \\
\text { підготовки, план основних заходів, } \\
\text { перелік основних подій тощо. } \\
\text { • Річна навчальна спрямованість } \\
\text { (міститься в оперативному плані). } \\
\text { • Спеціальний навчальний аналіз з } \\
\text { прив’язкою до бойових операцій. } \\
\text { • Стандарти експедиційних завдань. } \\
\text { • Принципи бойової готовності і } \\
\text { життєзабезпечення і Вимоги до } \\
\text { бойової готовості }\end{array}$ \\
\hline Планування & \begin{tabular}{ll}
\multicolumn{2}{l}{ Навчальний план: } \\
- & Аналіз викладання. \\
- & План оцінювання навчання. \\
- & Стратегії викладання. \\
- & Посилання і ресурси \\
\end{tabular} & $\begin{array}{l}\text { Специфікація навчань: } \\
\text { • Спрямованість підготовки і } \\
\text { керівництво з боку територіальних } \\
\text { командувань. } \\
\text { •План основних заходів }\end{array}$ \\
\hline Розробка & $\begin{array}{l}\text { Опрацювання: } \\
\text { • Закупівля навчального матеріалу. } \\
\text { • Підготовка матеріалів для } \\
\text { навчання. } \\
\text { •Підготовка виклаацького складу }\end{array}$ & $\begin{array}{l}\text { Загальний сценарій підготовки: } \\
\text { • Планування навчань. } \\
\text { • Керівництво з бойової підготовки. } \\
\text { • Інструкції для проведення навчань. } \\
\text { • Контрольний список для } \\
\text { проведення навчань. } \\
\text { • Організаційні інструкції. } \\
\text { •Підготовка о/с, який обслуговує та } \\
\text { організовує навчання }\end{array}$ \\
\hline Проведення & Проведене навчання: & Навчальні заходи з’єднань/ часин/ \\
\hline
\end{tabular}




\begin{tabular}{|c|c|c|}
\hline & $\begin{array}{l}\text { • Моніторинг змісту і навчання. } \\
\text { • Моніторинг викладацького } \\
\text { складу }\end{array}$ & підрозділів \\
\hline Оцінювання & $\begin{array}{l}\text { Оцінювання військових фахівців: } \\
\text { - } \quad \text { складання тестів/перевірок. } \\
\text { - } \quad \text { оцінювання тестів/перевірок. } \\
\text { Оцінювання програми: } \\
\text { - } \quad \text { підготовка пану оцінювання. } \\
\text { - } \quad \text { збір і аналіз даних. } \\
\text { - } \quad \text { інтерпретація виявленого. } \\
\text { - } \quad \text { висновки. } \\
\text { - } \quad \text { звіт і дії. } \\
\text { - }\end{array}$ & $\begin{array}{l}\text { Оцінювання навчання шляхом } \\
\text { вивчення звітів про результати } \\
\text { навчань: } \\
\text { • Група стандартизації та оцінювання } \\
\text { підготовки до бойового застосування } \\
\text { і бойової готовності. } \\
\text { •План підтвердження - чи засвоїв } \\
\text { підрозділ свої стандарти виконання } \\
\text { або потрібна додаткова підготовка }\end{array}$ \\
\hline Затвердження & $\begin{array}{l}\text { Збір і аналіз даних: } \\
\text { • Звіт і рекомендації }\end{array}$ & $\begin{array}{l}\text { Звіт про результати навчань: } \\
\text { • Звіт про підтвердження. } \\
\text { • Набутий досвід }\end{array}$ \\
\hline
\end{tabular}

Підчас навчання за освітньо-професійною програмою підготовки бакалавра та магістра за цивільними галузями знань, військові фахівці проходять базовий курс професійної підготовки L-1A. Останнім блоком навчальних дисциплін передбачається фаховий курс професійної підготовки L$1 \mathrm{~B}$ (взвод) терміном до 6 місяців. Така підготовка дозволить випускнику обіймати первинні посади (командир взводу, заступник командира роти). Перед призначенням на посаду командира роти офіцер проходить фаховий курс професійної освіти L-1C (рота) на базі видового ВBН3. На курсі L-2 здійснювати підготовку офіцерів органу військового управління, на L-3 керівника органу військового управління або офіцера органу військового управління на рівні Об’єднаного штабу, а на L-4 - вищого керівного складу для Штабів Командувань видів 3С України, ГШ 3С України, МО України. На L-5 курсах стратегічного управління вищого рівня та державної політики здійснювати навчання із керівним складом як сил оборони так і сил безпеки, а саме генералів та державних службовців. На курсі L-2 проводиться заняття в об'єднаних групах за видовою належністю, а на L-3 та L-4 - підготовка в об’єднаних групах без видової належності $[3,4,5]$.

Однією з головних вимог до офіцерів, які плануються для призначення на посади керівника органу військового управління або офіцера органу військового управління на рівні Об’єднаного штабу є здобуття ступеня вищої освіти магістр.

Підготовка на курсі L-1A, L-1B, L-1C та L-2 проводиться в об'єднаних групах за видовою належністю Збройних Сил України, а L-3, L-4 та L-5 - в об'єднаних групах без видової належності усіх сил оборони. Такий підхід дозволяє сформувати єдине розуміння щодо планування та ведення об'єднаних операцій $[6,7,8]$.

Професійна військова освіта забезпечує навчання впродовж життя. Воно пов'язане 3 набуттям компетентностей у різних умовах (індивідуальне, колективне та спільне навчання тощо) за допомогою видів освіти. Відповідно до Закону України "Про освіту" визначено види освіти, а саме формальна, 
неформальна та інформальна освіта. Для спеціалізованої освіти (військової освіти) притаманними є формальна та неформальна освіта.

Формальна освіта охоплює вищу освіту, а неформальна - професійну військову освіту та підвищення кваліфікації.

Формальна освіта передбачає досягнення здобувачами визначених стандартами вищої освіти результатів навчання відповідного рівня освіти (першого, другого, третього та наукового) i здобуття кваліфікацій, що визнаються державою.

Неформальна освіта поділяється на дві підсистеми: професійна військова освіта та підвищення кваліфікації. Професійна військова освіта - це спеціалізована освіта, яка здобувається у неформальній освіті за освітніми програмами з метою набуття відповідних рівнів військової освіти (тактичного, оперативного та стратегічного), вдосконалення професійного рівня військового фахівця, набуття фахових компетентностей, що забезпечують виконання службових (бойових) функцій.

Інформальне (необов'язкове) навчання $\epsilon$ незапланованим. Цей вид навчання відбувається стихійно. Це нецілеспрямований процес щодо здобуття компетентностей вдосконалюються в процесі військової служби. Випадкове навчання також може бути похідним від помилок, на які впливає той, хто навчається.

На основі концепції навчання впродовж життя освітня діяльність, незалежно від того, чи це проводить викладач, чи це самостійне навчання, полягає в тому, що військові фахівці повинні брати активну участь у навчальному процесі, оскільки вони найкраще навчаються завдяки цілеспрямованій, керованій, розумовій та фізичній діяльності. Викладачі (інструктори, розробники) шукають шляхи та змін щодо підвищення рівня навчання військових фахівців $[9,10,11,12]$.

Планування навчальної діяльності зосереджується на визначенні того, що військові фахівці повинні робити для вивчення матеріалу, а не на тому, що повинні робити викладачі для підготовки та проведення заняття. При такому підході викладач сприймається більше як тьютер, тренер та радник. Зосереджене навчання не стосується якоїсь конкретної навчальної стратегії, а скоріше багатьох різних навчальних ситуацій, що використовують підхід, зосереджений на навчанні.

Крім того професійна військова освіта забезпечує освіту дорослих. Застосовуючи андрагогічний підхід (навчання дорослих), військові фахівці постійно навчаються і найкраще вчаться, коли негайно застосовують придбані компетентності. Важливо створити сприятливі умови, позитивний психологічний клімат та забезпечити ефективні стратегії навчання. Викладач пропонує заходи, які орієнтовані на навчання, самонавчання та отримання досвіду. На навчання також впливає самоефективність - це упевненість людини у свою здатність здобути компетентності.

Професійна військова освіта застосовує гнучке навчання. Ця технологія надає можливості розширити можливості в аудиторії та поза межами. Гнучка освіта використовує навчання в аудиторії, а також розподілене та дистанційне 
навчання (електронне, мобільне, комп’ютерне). Гнучкому навчанню може сприяти поєднання різних методів. Своєчасна освіта, тісно пов'язана 3 концепцією навчання впродовж життя. Це має багато переваг, наприклад, зменшення ерозії знань та навичок. Це може викликати певні міркування 3 точки зору управління людськими ресурсами, оскільки має існувати відповідність між кваліфікацією, необхідною для виконання роботи, та потребами в навчанні діючого співробітника $[13,14,15]$.

Освітні заходи повинні бути результативними та ефективними. Зайві навчальні заходи витрачають матеріальні, фінансові та людські ресурси. Тому професійна військова освіта заснована на спільному процесі, в рамках управління, є життєво важливою для забезпечення оптимальних результатів. Усі освітні заходи розробляються та реалізуються найрезультативнішими та найефективнішими засобами [16, 17,18].

Для забезпечення якості професійної військової освіти створюється відповідна система та порядок їі вимірювання, що містить чотири складові: інспектування, контроль якості, гарантування якості та забезпечення якості, а came:

1) моніторинг та перегляд програм освіти;

2) визначення та задоволення потреб зацікавлених сторін;

3) забезпечення потреб замовників;

4) відповідальність за якість;

5) охоплення усіх структурних елементів організації, залучення усього особового складу організації;

6) виявлення та виправлення помилок;

7) системний підхід до виявлення та усунення проблем на кожному етапі процесу.

Висновки та перспективи подальших наукових досліджень. В результаті трансформації професійної військової освіти будуть отримані наступні результати:

1. Створення єдиної уніфікованої системи підготовки персоналу для сил оборони з урахуванням досвіду держав-членів НАТО.

2. Формування ефективної системи професійної військової освіти, яка інтегрована в державну систему освіти.

3. Досягнення сумісності зі збройними силами держав-членів НАТО шляхом впровадження у системі професійної військової освіти процесів планування та прийняття військових рішень.

4. Забезпечення централізованої підготовки особового складу сил оборони оперативного та стратегічного рівнів.

5. Професійна військова освіта формує військову еліту держави, готує компетентних військовослужбовців-лідерів.

6. Реалізація принципу «Освіта впродовж військової кар’єри».

7. Забезпечення якості вищої освіти та професійної військової освіти у відповідності 3 вимогами стандарту HATO Bi-SCD 075-007 «Освіта та підготовка». 
8. Створення умов для акредитації військової освіти у вищих військових навчальних закладах з урахуванням потреб та специфіки сил оборони.

9. Формування передумов щодо взаємовизнання сертифікатів, отриманих у військових навчальних закладах держав-членів НАТО.

Перспективи подальших досліджень полягають у навчанні, що максимально реалістично відтворює чи імітує оперативні умови бойових дій. Через безпеку та обмеження ресурсів, навчання не може охопити всі потенційні оперативні ситуації, тому необхідно оптимізувати можливості навчання шляхом вибору сценаріїв та моделювання, які $\epsilon$ репрезентативними, стимулюючими, складними та непередбачуваними, але не двозначними із залученням спільних, багатонаціональних та цивільних учасників.

\section{ЛІТЕРАТУРА}

1. DAOD 5031-1, Програма збройних сил Канади.

2. DAOD 5031-2, Стратегічні рамки індивідуальної підготовки та навчання.

3. DAOD 5031-4, Мережева програма допомоги у другій кар'єрі.

4. DAOD 5031-5, Програма безперервної освіти збройних сил Канади.

5. DAOD 5031-7, Початкова бакалаврська програма.

6. СFАО 11-6, Політика введення в службу та просування - офіцери - регулярні війська.

7. СFAO 49-12, Політика просування - Офіцери - Основний резерв.

8. $\mathrm{ADM}(\mathrm{HR}-\mathrm{Mil})$ Instruction 05/05, Нові умови служби у регулярних військах ЗСК.

9. CF Mil Pers Instr 02/07, Структура повноважень та управління - Структура зайнятості військових.

10. А-Р9-050-000/РТ-001, Посібник 3 індивідуальної підготовки та навчання збройних сил Канади, том 1 , Вступ/Опис.

11. А-РА-005-000/АР-001, Обов'язок з честю - професія зброї в Канаді.

12. А-РА-005-000/АР-004, Лідерство у збройних силах Канади: Концептуальні основи.

13. А-РА-005-000/АР-005, Лідерство у збройних силах Канади: керівництво людьми.

14. А-РА-005-000/АР-006, Лідерство у збройних силах Канади: керівництво установою.

15. Серія публікацій A-PD-055, Посібник збройних сил Канади з військової професійної структури.

16. Естонський національний коледж оборони. - [Електронний ресурс]. - Режим доступу: https: // www.ksk.edu.ee.

17. Офіцерська школа Естонського національного коледжу оборони. - [Електронний pecypc]. - Режим доступу: https: // www.sojakool.ee.

18. Балтійський оборонний коледж. - [Електронний ресурс]. - Режим доступу: https: // www.baltdefcol.org.

\section{REFERENCES}

1. DAOD 5031-1, Programa zbrojnih sil Kanadi.

2. DAOD 5031-2, Strategichni ramki individual'noï pidgotovki ta navchannya.

3. DAOD 5031-4, Merezheva programa dopomogi u drugij kar'eri.

4. DAOD 5031-5, Programa bezperervnoï osviti zbrojnih sil Kanadi.

5. DAOD 5031-7, Pochatkova bakalavrs'ka programa.

6. CFAO 11-6, Politika vvedennya v sluzhbu ta prosuvannya - oficeri - regulyarni vijs'ka.

7. CFAO 49-12, Politika prosuvannya - Oficeri - Osnovnij rezerv. 
8. $\operatorname{ADM(HR-Mil)~Instruction~05/05,~Novi~umovi~sluzhbi~u~regulyarnih~vijs'kah~ZSK.~}$

9. CF Mil Pers Instr 02/07, Struktura povnovazhen' ta upravlinnya - Struktura zajnyatosti vijs'kovih.

10. A-P9-050-000/PT-001, Posibnik z individual'noï pidgotovki ta navchannya zbrojnih sil Kanadi, tom 1, Vstup/Opis.

11. A-PA-005-000/AP-001, Obov'yazok z chestyu - profesiya zbroï v Kanadi.

12. A-PA-005-000/AP-004, Liderstvo u zbrojnih silah Kanadi: Konceptual'ni osnovi.

13. A-PA-005-000/AP-005, Liderstvo u zbrojnih silah Kanadi: kerivnictvo lyud'mi.

14. A-PA-005-000/AP-006, Liderstvo u zbrojnih silah Kanadi: kerivnictvo ustanovoyu.

15. Seriya publikacij A-PD-055, Posibnik zbrojnih sil Kanadi z vijs'kovoï profesijnoï strukturi.

16. Estons'kij nacional'nij koledzh oboroni. - [Elektronnij resurs]. - Rezhim dostupu: https: // www.ksk.edu.ee.

17. Oficers'ka shkola Estons'kogo nacional'nogo koledzhu oboroni. - [Elektronnij resurs]. - Rezhim dostupu: https: // www.sojakool.ee.

18. Baltijs'kij oboronnij koledzh. - [Elektronnij resurs]. - Rezhim dostupu: https: // www.baltdefcol.org.

\section{PЕЗЮМЕ}

Виталий Рахманов, доктор педагогических наук, доцент Национальный университет обороны Украины имени Ивана Черняховского

\section{Основные подходы к системе профессионального военного образования в Украине}

В статье рассматриваются изменения, происходящие в последнее время, в системе профессионального военного образования в Украине. Проанализированы системный подход к обучению, который обеспечивает методологию для анализа необходимости в обучении, определение наиболее необходимой учебной стратегии, разработки и проведения учебных и образовательных мероприятий, а также оценки и подтверждения результатов, обеспечивающих обратную связь для совершенствования компетентностей военных специалистов, где рядом с образованием необходимо учитывать условия службы, стимулы и мотивацию. Предложенные принципы профессионального военного образования, которые обеспечивают на основе непрерывного развития военных специалистов и остаются неотъемлемой составляющей высшего образования в Украине. Для обеспечения качества профессионального военного образования определена система обучения по совместной подготовки офицерского состава тактического, оперативного и стратегического уровня Вооруженных Сил Украины и их составляющих сил безопасности и обороны с целью получения военными специалистами новых компетенций, операционной совместимости на основе стандартов принятых в вооруженных силах государств-членов НАТО.

Ключевые слова: профессиональная военное образование, приобретение компетентностей, подготовка будущих специалистов, образовательная деятельность. 


\section{SUMMARY}

Vitaliy Rakhmanov,

Dr. (Pedagogical Sciences), associate professor National Defense University of Ukraine named after Ivan Chernyakhovskyi

\section{Main approaches to the professional military system education in Ukraine}

The article considers the recent changes in the system of professional military education in Ukraine. A systematic approach to training is analyzed, which provides a methodology for analyzing the need for training, determining the most appropriate training strategy, developing and conducting training and educational activities, as well as evaluating and validating results that provide feedback to improve the competencies of military professionals. with education it is necessary to take into account the conditions of service, incentives and motivation. The principles of professional military education are proposed, which are provided on the basis of continuous development of military specialists and remain an integral part of higher education in Ukraine. To ensure the quality of professional military education, a system of training on joint training of officers of the tactical, operational and strategic level of the Armed Forces of Ukraine and their components of security and defense forces has been defined in order to provide military specialists with new competencies NATO. .

Key words: professional military education, acquisition of competencies, training of future specialists, educational activity. 